\title{
The Case of "Anis del Mono" Factory. Regenerating Coastal Heritage in Catalonia
}

\author{
By Anna Martínez Duran* \\ Jordi Gordon Guerra \\ Xavier Martín Tost ${ }^{+}$ \\ Anna Peguero Piquer ${ }^{\dagger}$
}

The "IAM group" (Investigation in Mediterranean Architecture), School of Architecture La Salle - URL, Barcelona, has developed a research project entitled "Strategies for Sustainable Regeneration of Touristic Settlements in the Mediterranean coast". The aim of this investigation is to establish sustainable recycling rules to improve the development of abandoned or obsolete public spaces and buildings on the Catalan seafront. In its aim to restore the coastal heritage, the study focuses on the Modernist factory of Anis del Mono as a case study, and proposes the optimization of existing facilities and an extension of the program with new public uses. The operation aims to establish an open dialogue with the environment, improving the relation with the sea and the city, becoming a reference on the city shoreline. The results of successfully completed architectonic projects can provide us with some universal guidelines that can be used as parameters in similar cases along the whole coast. These transformation strategies are the final goal of our research and are included at the end of the presentation.

Keywords: Architectural rehabilitation, Coastal heritage, Mediterranean architecture, Sustainability, Tourism.

\section{Introduction}

The Mediterranean Architecture research group: IAM (Investigation on Mediterranean Architecture), School of Architecture La Salle - URL, Barcelona (Spain) works on the architecture and urban design in the Mediterranean area, and is concerned with all the aspects of the design process: from territory to detail.

The research areas of the group are focused on the study of the special features of the Mediterranean building structures: their setting on the land, the use of natural materials and the presence of intermediate spaces and passive systems for climate protection. All of these constructive and urban values are

\footnotetext{
* Architect \& Coordinator Group IAM, Ramon Llull University, Spain.

* Architect \& Researcher, Ramon Llull University, Spain.

${ }^{+}$Architect \& Researcher, Ramon Llull University, Spain.

${ }^{\dagger}$ Architect \& Researcher, Ramon Llull University, Spain.
} 
found in vernacular architecture and included in the Modern Movement buildings.

The general aim of the group is to recover, through the application of a technical and critical approach, this specific construction and settlement in order to provide guidelines to solve some contemporary problems, such as how to build in an environmentally efficient way.

The group has developed a Research Project "Strategies for the Sustainable Regeneration of Touristic Settlements on the Mediterranean coast" (IAM 2015).

\section{Research Project: "Strategies for Sustainable Regeneration"}

The aim of this investigation is to establish sustainable recycling rules to improve the development of abandoned or obsolete public spaces and buildings in the Catalan seafront.

The purpose is not to develop specific architectonic projects, but to design transformation strategies, that can be used as parameters in similar cases along the whole coast.

This research is based on the hypothesis that a one-off intervention in some strategic architectural or urban elements would mark the beginning of the regeneration of the surrounding environment.

The final target of the Research Project is to recover the cultural and architectonic identity of these settlements, preserving their natural and humanistic landscape. The group collaborates with different organizations and institutions, either public or private, related to the different topics.

\section{Index and Territorial Maps}

During the first part of the project a typological map of the Catalonia coastal land, $500 \mathrm{~km}$ long and $20 \mathrm{~km}$ wide, was designed (see Figure 1). It became the base over which all the investigation was developed, and the case studies situated.

It created the need of define drawing criteria for the subjects of interest, selecting topography, hydrographs, urban settlements and big territorial structures, such as main roads and railways (Busquets 2003, 2004).

Figure 1. Typological Map of Catalonia's Coast

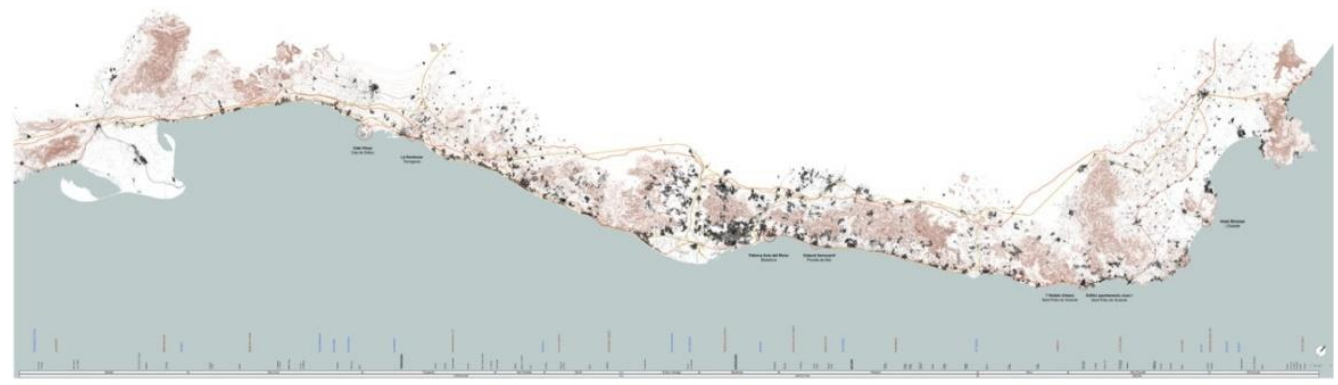

Source: Investigation on Mediterranean Architecture. 
The next stage was to carry out a detailed reading of the sites (see Figures 2 and 3). These analysis had to include an accurate overview of their historical, cultural and social heritage, in order to determine the causes of their degradation (Solà-Morales 1997, Kostof 2004, Marshall 2005).

Figures 2 and 3. Examples of Territorial Maps (Settlements and Uses)
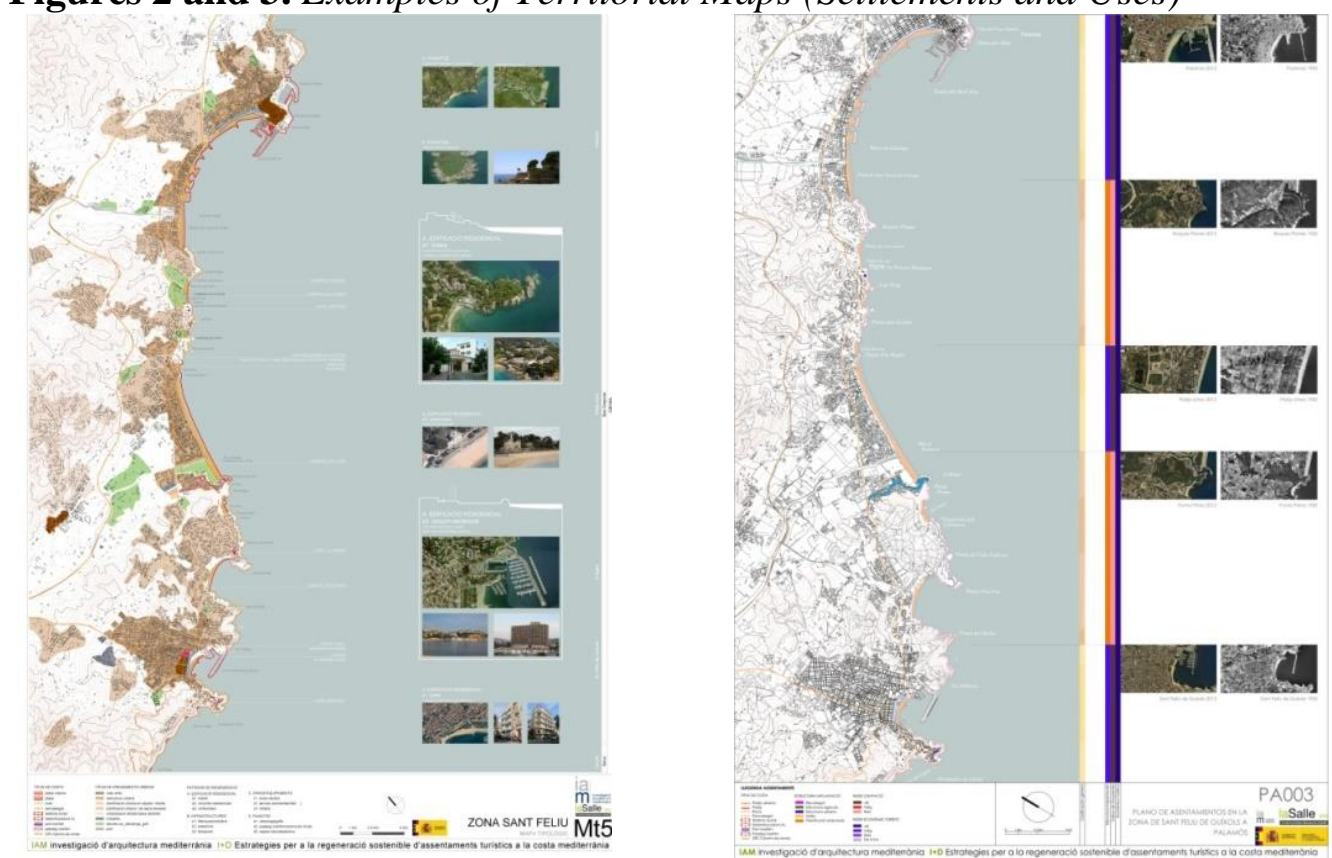

Source: Investigation on Mediterranean Architecture.

Study Cases

Various problems were detected in the coastal analysis, which have been grouped in seven thematic typologies. In each area, a particular building has been chosen to develop a specific analysis and to propose a regeneration project (Martí 1990, Monteys 2014). The different categories and the selected study cases were:

\section{Unused Hotels in Touristic Towns}

Catalan coastal hotels are directly related to temporary tourism, which tends to be concentrated in summer. Most of the hotels were built 40 or 50 years ago, at the beginning of the Spanish touristic boom, and they have not been renovated. Consequently, they offer an out-dated and unattractive touristic product for today's holiday-makers. This situation has important urban consequences and affects the image of the cities. In most cases, an architectonic solution should provide an updated solution to present-day tourist demands.

Case study: seven urban hotels which are now closed and in a public auction process, in the urban centre of Sant Feliu de Guíxols (Girona). The project proposes renovation of the hotel and the neighbouring residential buildings which would maintain traditional façades and include public services 
around a central patio, so that the area can be used all the year and open to the rest of the city.

\section{Big Public Buildings over the Seafront}

Some important public buildings, due to their history or their property complexity, remain unalterable on the seafront, for example, some sanatoriums or military areas. These are public buildings that cannot be maintained sustainably if they are not reused, refurbished and modernized.

Case study: the ancient "La Savinosa" sanatorium, situated in a little cliff near the city of Tarragona. The building complex was built in 1929 as a tuberculosis hospital, but is abandoned since 1978. For this particular case, a new use is outlined, as a hotel and cultural space, and proposed to convert the environment into a public leisure zone.

\section{Low Density Resorts}

The promotion of low density touristic resorts over the seafront is a touristic model which is not really common in the Catalan coast, but there are some high quality examples. They offer temporary accommodation with a good provision of services and exclusive resort buildings. Their current problems have to be analysed from a contemporary vision.

Case study: Cala Vinya complex, designed by the architect Antonio Bonet Castellana in 1964, located in Cap Salou (Tarragona). Our project considers the transformation of the abandoned hotel in an assisted-living block of apartments, and the rehabilitation of the rest of public services and spaces.

\section{Cultural Areas at the Sea Front}

The coastal touristic towns require open spaces for temporary cultural uses. The adequacy of the waterfronts, seaports and maritime promenades optimizetheir unique landscape.

Case study: the harbour of Sant Feliu de Guixols is used as a public space, but it has a strong disorder of functions and circulations. A rehearsal stage for the international musical "Festival Porta Ferrada" is proposed, a concrete terrace with sweeping views over the bay and steep topography behind. The project also includes a dry dock underneath to combine different uses in a unique building.

\section{The Emblematic Touristic Hotel}

The presence of a historical hotel in a touristic town could be a representative icon for the city and the territory. One of the deficits of the touristic capitals of the Catalan coast is that they have never had the opportunity to build an emblematic hotel and thus they have never been able to reinforce 
their image of luxury travel destinations. The analysis refers to those lost opportunities.

Case study: the "Panorama" hotel situated in Sant Feliu de Guíxols (Girona) is an example due to its unique position, at the top of the old city, with a recognizable skyline which can be seen from the beach. Surrounded by ancient gardens, it has great potential to be converted in a luxury and emblematic hotel.

\section{Conversion of Services and Infrastructures}

A number of connexion infrastructures and services built along the Catalan coast have been renovated, but many others have to be demolished, refurbished or modernised, because they are not in keeping with landscape or are simply obsolete. This is the situation of some railways, industrial tanks, energy stations, rubbish dumps or purifying plants. The aim of our work is to analyse their different situations and their territorial compatibility, establishing other uses and their modernisation.

Case study: the railway over the Maresme seafront in Barcelona prevents a transition flow from the cities to the beach. We propose a study of the railway stations, some of them in disuse, in order to convert them into public spaces to facilitate and embellish this connection.

\section{$\underline{\text { Recuperation of Coastal Heritage Buildings }}$}

The existence of an important number of historical buildings along the Catalan seafront, protected as a monument, usually represents a problem of uses, building maintenance, and relation to the closer context.

Case study: the "Anis del Mono" factory on the seafront of Badalona (Barcelona). Its peculiar location and historical value as a Modernist building are the reasons why this building has been protected by the local council.

\section{The "Anis Del Mono" Factory. A Particular Study Case}

The next step of the research is to develop an architectonical project to provide solutions to each one of the seven case studies. These examples represent the problems detected on the coast which have the potential to regenerate the surrounding environment.

The proposal involves a territorial approach, a diagnosis of the situation and an architectonical project. In each case it is necessary to detect the reasons which have led to the current situation and to propose actions for the regeneration of the building and its surroundings. The transformation project should include the rehabilitation of the building with introduction of new uses.

The resolution of these seven cases has resulted in certain common patterns that are presented at the end of the paper as strategic guidelines. 
The "Anis del Mono" factory is a landmark in the landscape of Badalona, because of its situation on the seafront (see Figure 4). The complex is located in a narrow strip between the railway and the beach. It was built in 1870, but at that time the sea side was not a point of interest, so the main entrance was placed facing the railway, permitting the deliveries and the transporting of materials (see Figure 5).

The first Modernist buildings have been expanded in an anarchic way to the present. The factory is still in use, producing anisette, according to the ancient devices and techniques employed in the liqueur production.

Figure 4. Sea façade. Landmark towards Seafront

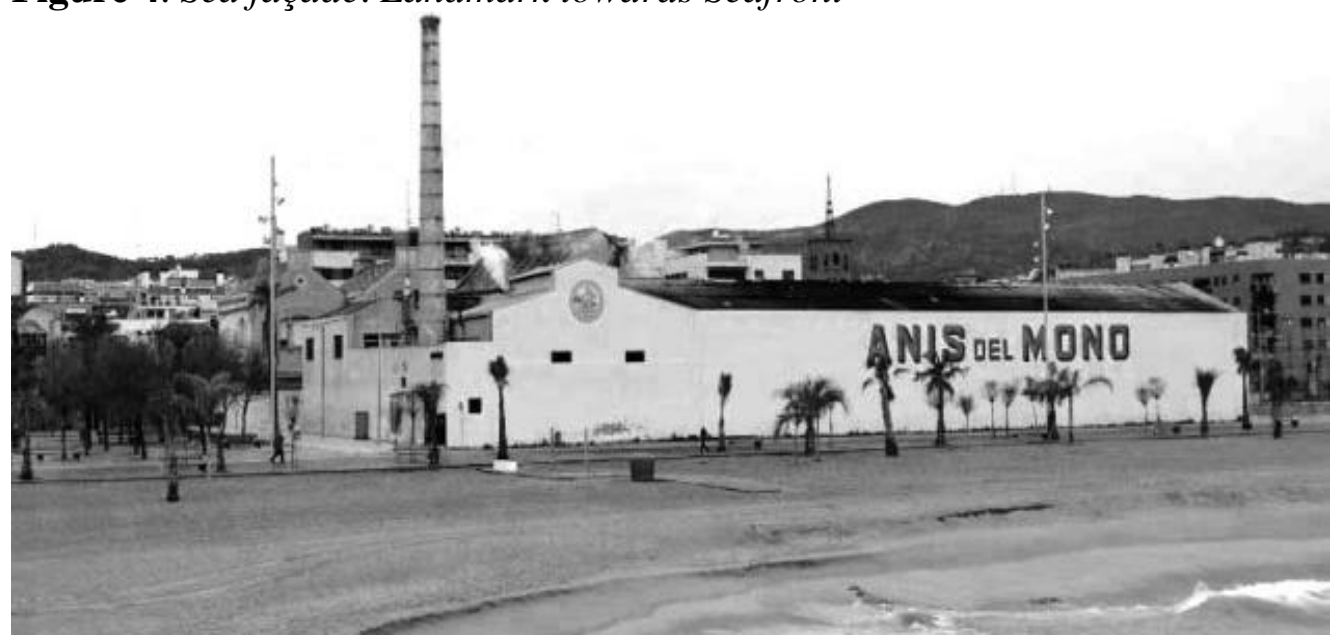

Source: Investigation on Mediterranean Architecture.

Figure 5. Railway Façade. Historical Main Entrance

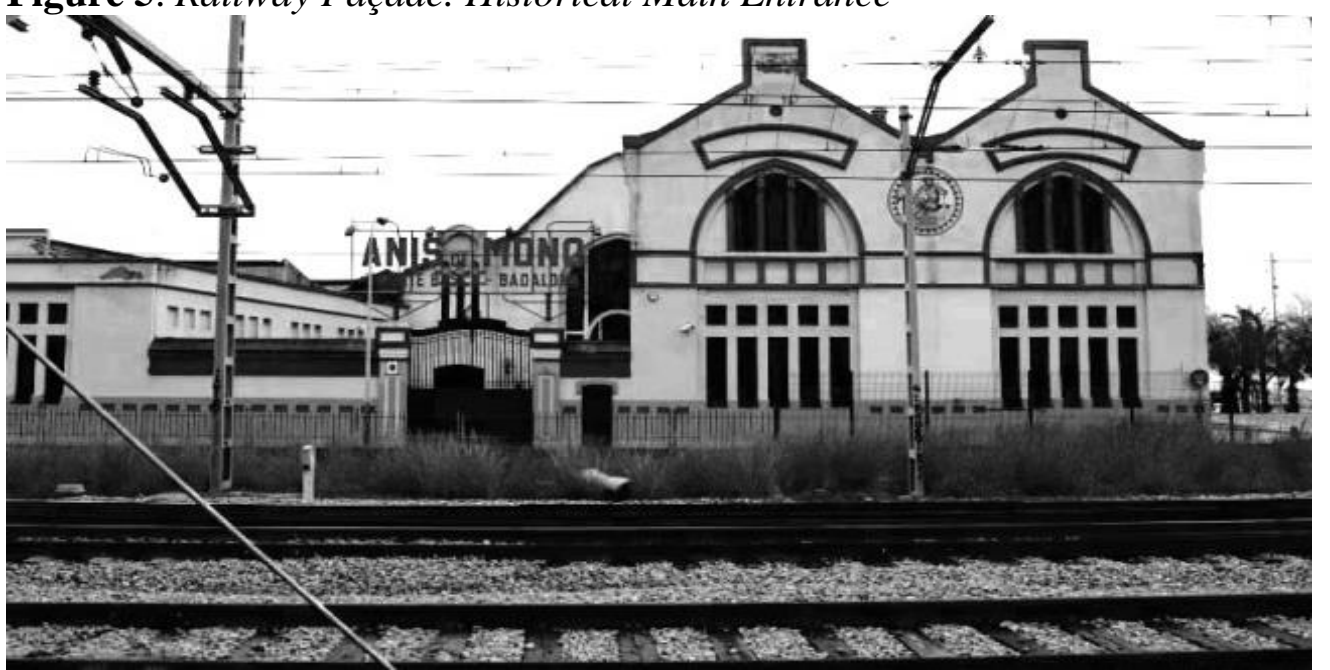

Source: Geological and Cartographic Institute of Catalonia.

In the main façade the entrance still stands as it was built, with the logo over the two columns and the historical sheds built by the architect Joan Amigó Garriga. 
The façade in front of the sea is a long blind wall, made of simple material and without any decoration, where the name of the institution covers the whole space (see Figure 6).

Figure 6. Re-drawing of Current Façades

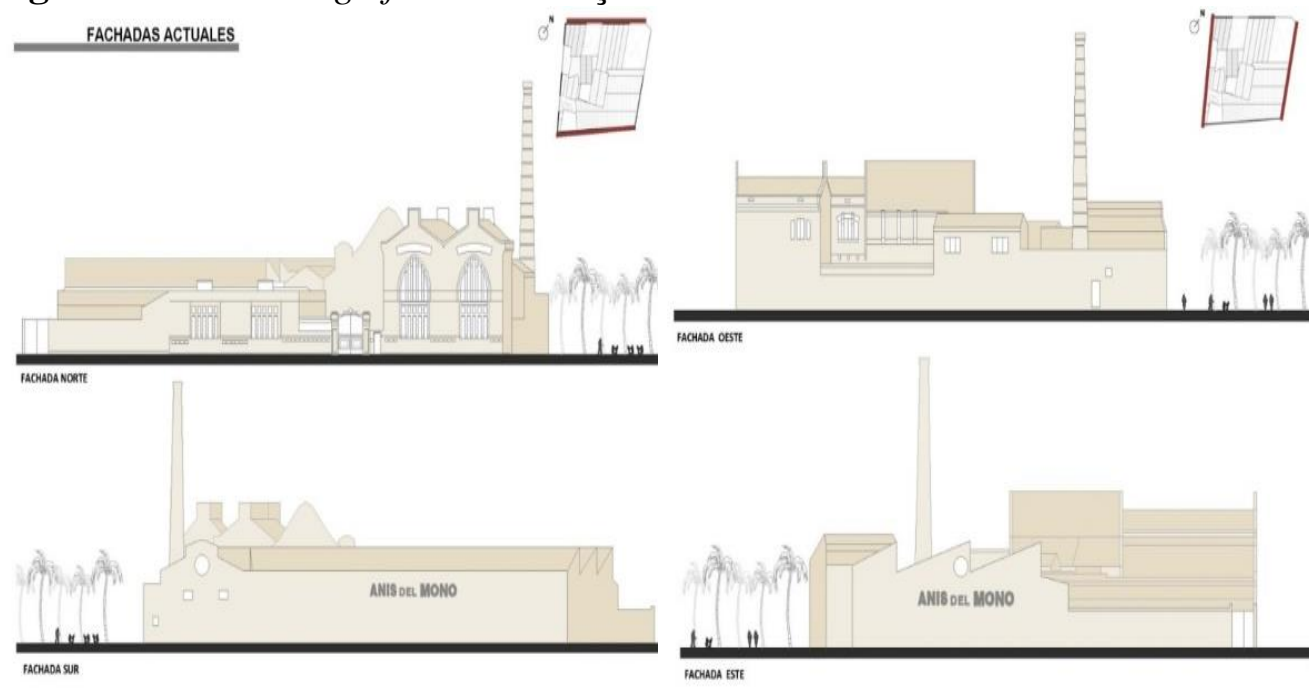

Source: Investigation on Mediterranean Architecture.

The building complex is composed of industrial sheds, organized around a squared patio. The main entrance is through this empty space. The factory has two floors, the ground floor with all the services to make the anise and the second one destined to management office space. The building presents a loadbearing wall structure, mixed of wood and ceramic.

Figure 7. The West Side of the Building, Facing the Sea

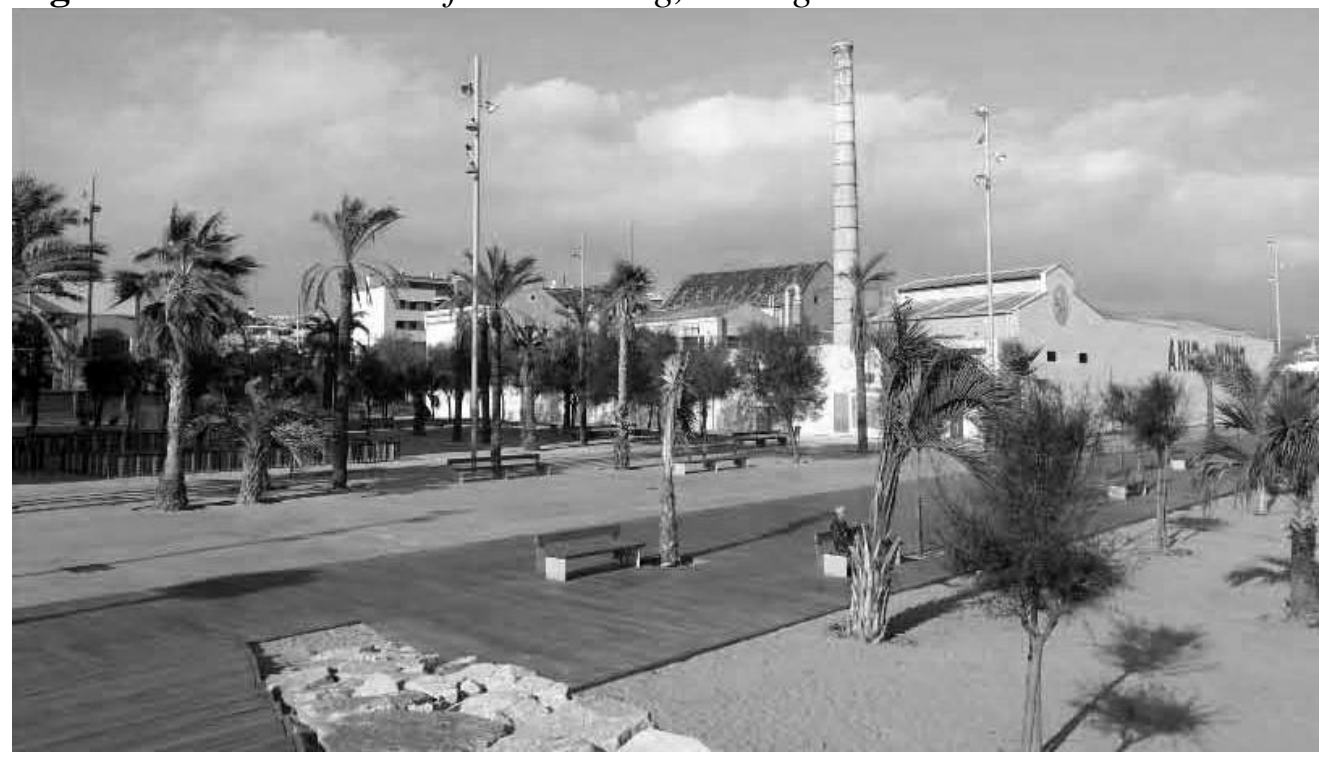

Source: Investigation on Mediterranean Architecture. 
Recently the municipality has built-up a new promenade running along the seafront and a public square in the west limit of the factory (see Figure 7). Facing the back of the building there is a wooden bridge called "El pont del Petroli", a walkway which enters the sea.

\section{New Program, New Facilities}

The architect must work with the sensitiveness of an interpreter and also with structural correction, ensuring that its intervention is understandable and attractive as well as useful (Ramos and Ramos 1995). However, the heritage preservations cannot be isolated from implementing new uses. Only the introduction of new functions together with existing ones can properly protect the building's heritage (see Figure 8).

The IAM group has demonstrated, as a result of discussions with different administrations and the current owner, the interest to improve the use and the image of the building, while maintaining the traditional production processes.

The proposed project aims to regenerate the factory by optimizing the existing facilities and extending the program with some public uses, such as a restaurant and a museum. This operation aims to establish an open dialogue with the environment, becoming a building of reference on Badalona shoreline.

The intervention acts only on the non-protected parts, trying to enhance the value of the entire historical building, improving its relation with the city.

Figure 8. Proposal: Ground floor, First Floor and Second Floor


Source: Investigation on Mediterranean Architecture. 
On the one hand, we agree with the owner's need to rationalize the process, and to dignify the industrial locals. It is very important to build an attractive space where people could see and understand anisette production by looking at the old equipment and traditional processes.

On the other hand, the project supports the proposal to open a new maritime museum in the city. This will collect all the existing information, from the Historic Archive and other collections, about the old beach, the different kinds of fishing boats, and some historical activities related to the sea.

The new public uses: the museum, a thematic store and restaurant, will be situated on the upper level, opening a new front towards the sea, while the production section remains on the ground floor around the existing patio and facing the railway.

\section{A New Relation with the City}

The main aim of the intervention is to preserve the existing buildings of the Modernist era and to ensemble them to the city and the sea. In this way the project removes the lateral wall that closes the building to the square, but maintains the existing chimney that marks the main entrance and becomes a powerful attraction for the future maritime museum (see Figure 9).

Figure 9. Proposal Façades

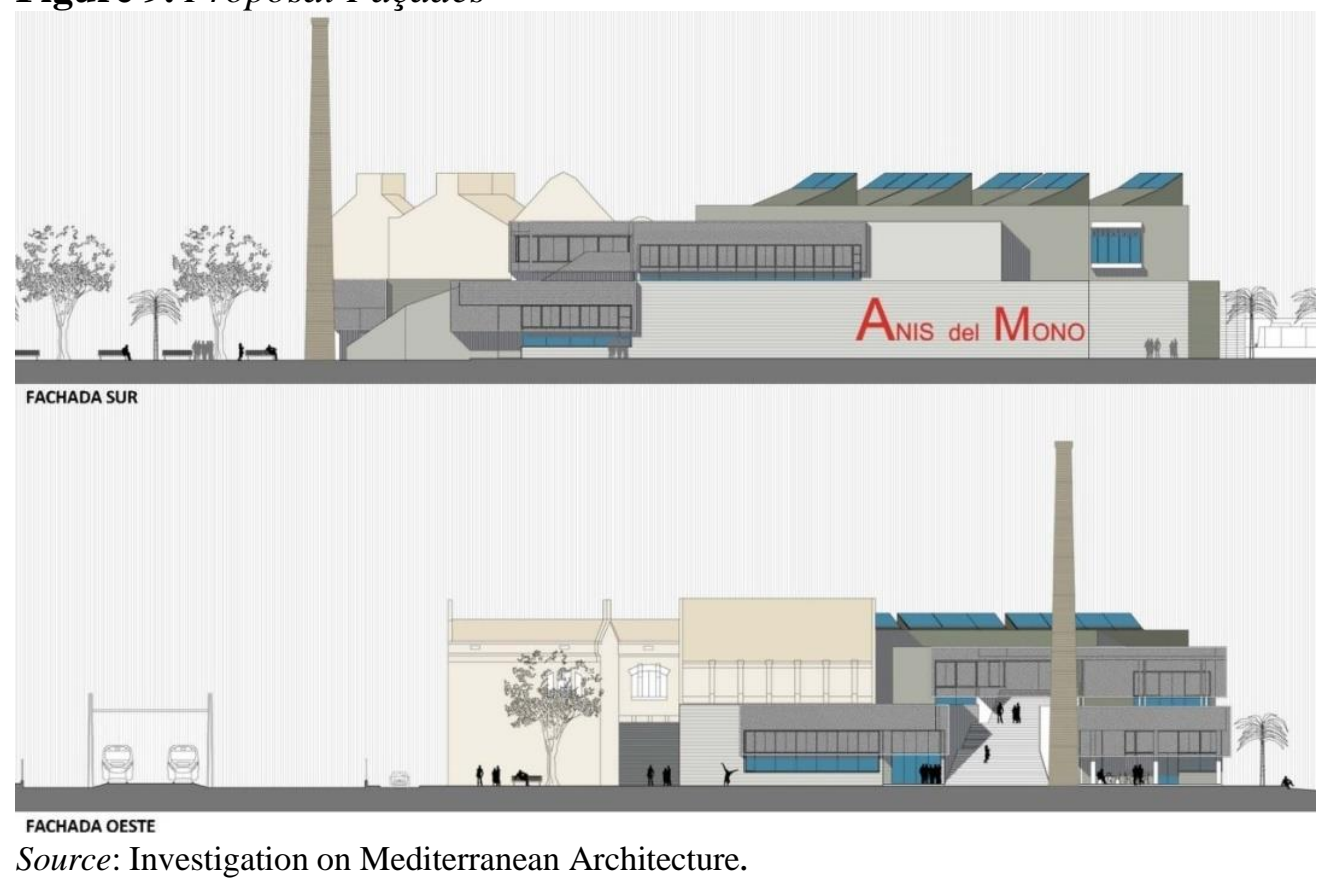

\section{Sustainability in Constructive and Climatic Details}

The whole building project has been developed in order to reach a high degree of sustainability (Mañá et al. 2003). 
The roof of the maritime museum will have skylights opening to the north, permitting a very good light control for exhibitions. It collects water cooling and isolating the rooms underneath, and solar panels were also proposed, which could generate enough energy to power the industry.

Some of the new façades are protected with deployed sheets to prevent insulation (Pardal and Paricio 2006). All the windows panes are low-heat emission. These strategies enable the building to function at almost zero energy costs. Isolation is also provided through the rest of insulation materials.

This project is developed in accordance with a life cycle assessment study (LCA), and some passive solar strategies have also been introduced to take advantage of the climate, using low-impact building materials (see Figure 10).

Figure 10. Proposal. Technical Detail of the Façade


Source: Investigation on Mediterranean Architecture.

\section{General Guidelines for Sustainable Regeneration}

The completion of particular cases such as this one, from the territorial scale to a construction detail, has allowed the researchers to extract some strategies of sustainable regeneration.

These strategies can be used as actions to inspire similar rehabilitations along the coast cases. Below are some of these guidelines, exemplified with images from the objects of study analysed, and symbolized by specific icons.

Each one of these icons represents a specific action in order to regenerate a building and its surroundings (see Figure 11). These drawings can be used as a graphical system which identifies all different interventions for setting up the starting point of a regeneration project. 
Figure 11. Regeneration strategies and specific icon: Paying attention to the place (A); Setting the Building on the Ground (B); Relating with the city through open ground floor (C); Ordering Functions and Circulations (D); Preserving the Original Structure (E); Maintaining the Courtyard, Shape and Atmosphere (F); Improving Climate Spaces and Habitability $(G)$.


Source: Investigation on Mediterranean Architecture.

\section{Paying Attention to the Place}

It means to contemplate the culture and nature of the place, according to the specific conditions of Mediterranean architecture. In all cases a preliminary analysis must be carried out, setting out the historical context, landscape and its evolution. The proposed actions have to fit in the present situation and generate new living conditions based on this consideration. Enjoying the environment or doing cultural or recreational activities enriches these populations, usually located in singular spots that need protection (see Figure 12).

Figure 12. "Hotel Panorama" in Sant Feliu de Guíxols

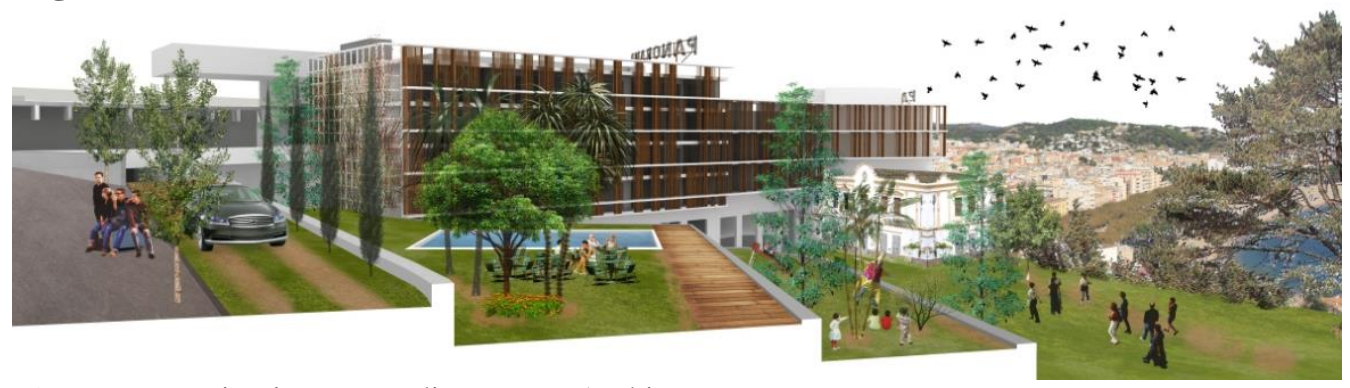

Source: Investigation on Mediterranean Architecture.

\section{Setting the Building on the Ground}

The adaptation to the topography is a condition that rarely occurs in the conventional architecture we find in the study.

In most projects the concordance with the level of support must be resolved, and this sometimes includes the modification of the subsoil. The architectural treatment of this correspondence to the existing field belongs to the Mediterranean traditional constructive logic. Sometimes, it provides the 
possibility of expanding the building underground without modifying the urban landscape. Finally buildings provide new spatial and environmental attractions (see Figure 13).

Figure 13. Old Sanitarium "La Savinosa" in Tarragona



Source: Investigation on Mediterranean Architecture.

Relating with the City through Open Ground Floor

The ground level is that thick layer through which people walk on and from which the buildings connect with residents.

The research prioritizes pedestrians and city users, and so we propose the ground floors -which extends to basements and mezzanines- open, transparent and accessible. The same operation involves rationalizing traffic, providing clear accesses, downloading parking of vehicles, and separating the pedestrian circulations, which remain linked to the public space (see Figure 14).

Figure 14. "Hotel Portalet Boulevard" in St. Feliu de Guíxols

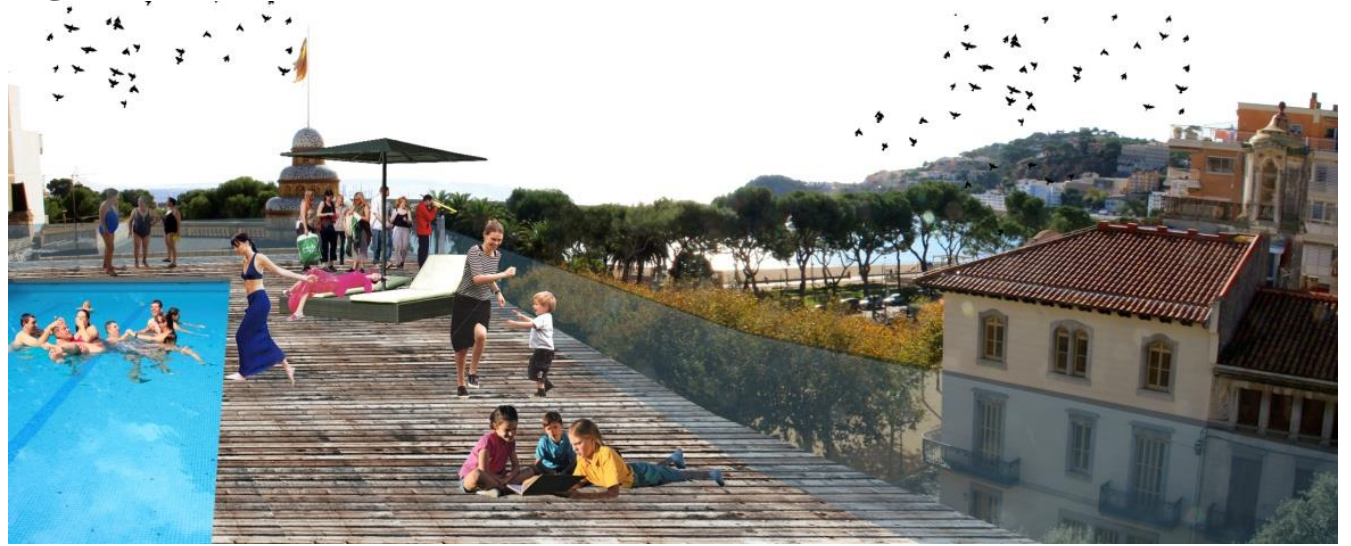

Source: Investigation on Mediterranean Architecture. 


\section{Ordering Functions and Circulations}

Most of the buildings under consideration have reached the end of their useful life after multiple and low construction quality renovations. In these cases it is necessary to proceed to a survey of their architectural quality, prior to proposing the new organization. The works consist in the analysis of the functional system of the building, their circulations and hierarchy of uses, in the way to rationalize them.

The result is a return to the pure geometry of the patios, to the clean lines of the eaves, to the volumetric sincerity, which provide architectural clarity and Mediterranean character to these constructions. This consideration allows us to include new programs without modifying the original volume configuration, or to add value to existing architectural elements, such as decks (see Figure 15).

Figure 15. Railroad Station in Premià de Mar

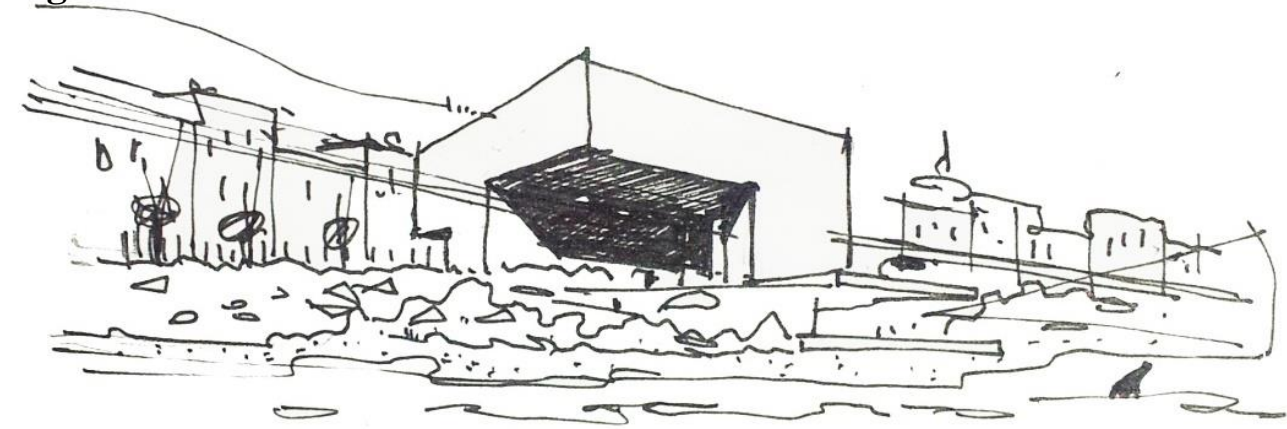

Source: Investigation on Mediterranean Architecture.

\section{Preserving the Original Structure}

Figure 16. "Hotel Portalet Boulevard" in St. Feliu de Guíxols



Source: Investigation on Mediterranean Architecture. 
Another of the detected patterns consists in keeping the original structure of the building, assessing and strengthening its construction features, modifying them promptly to adapt to new uses and to reinforce the order and unity of the building.

As a basic principle of sustainability, the different cases maintain the existing bearing walls, in stone or brick, the concrete or metal structures, and sometimes the attractive, stone or ceramic, traditional vaults (see Figure 16).

\section{Maintaining the Courtyard, Shape and Atmosphere}

The courtyard is built in the Mediterranean tradition as the space that structures and brings order and environmental quality to architecture. It is valued especially in reforms in historic buildings or complexes formed by various buildings. In both cases this empty space, which is associated to circulations and common spaces, has sufficient entity to provide unity to the formal structure, in addition to character, atmosphere and setting for community life (see Figure 17).

Figure 17. "Hotel Portalet Boulevard" in St. Feliu de Guíxols

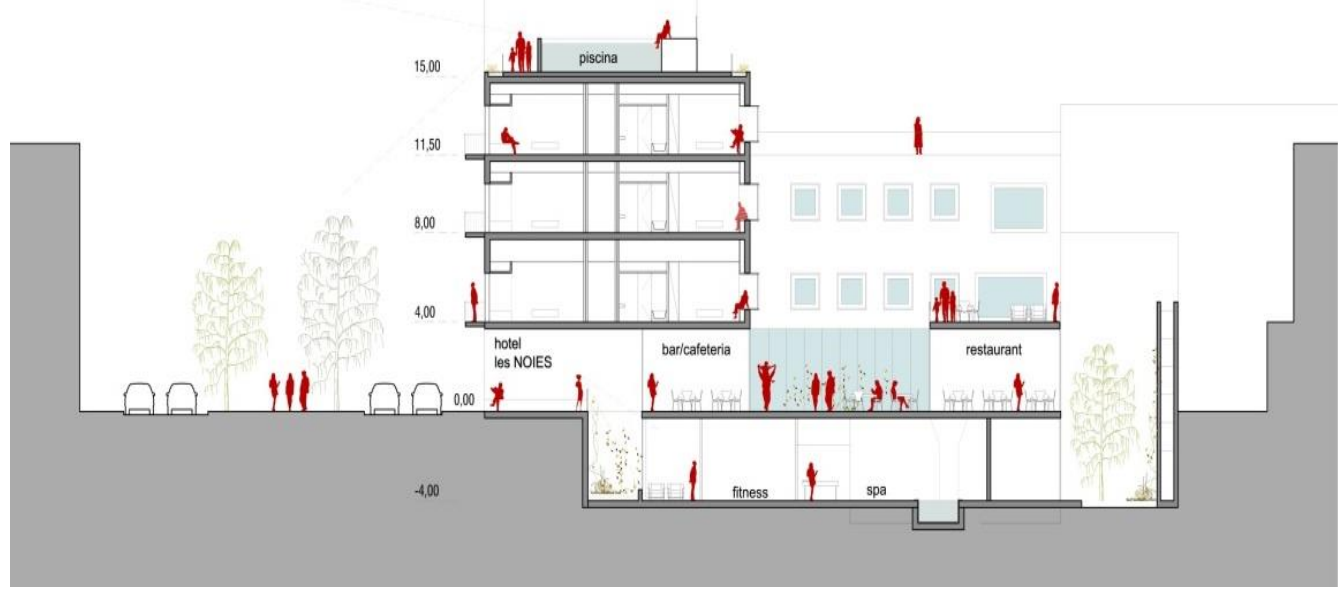

Source: Investigation on Mediterranean Architecture.

\section{Improving Climate Spaces and Habitability}

Liveability and energy needs have changed since the original construction of these buildings. This involves a review of the building climate conditioning systems, which now are solved by prioritizing passive systems.

Sometimes light facades are attached to the buildings to allow climate control. This provides flexibility in the use of the enclosures, with overlapping filters of different character, keeping the compositional unity of the project. Decks and roofs are also modified, introducing elements of shadow and pools, turning them into living spaces with climate control systems (see Figure 18). 
Figure 18. "Hotel Cala Vinya" in Salou

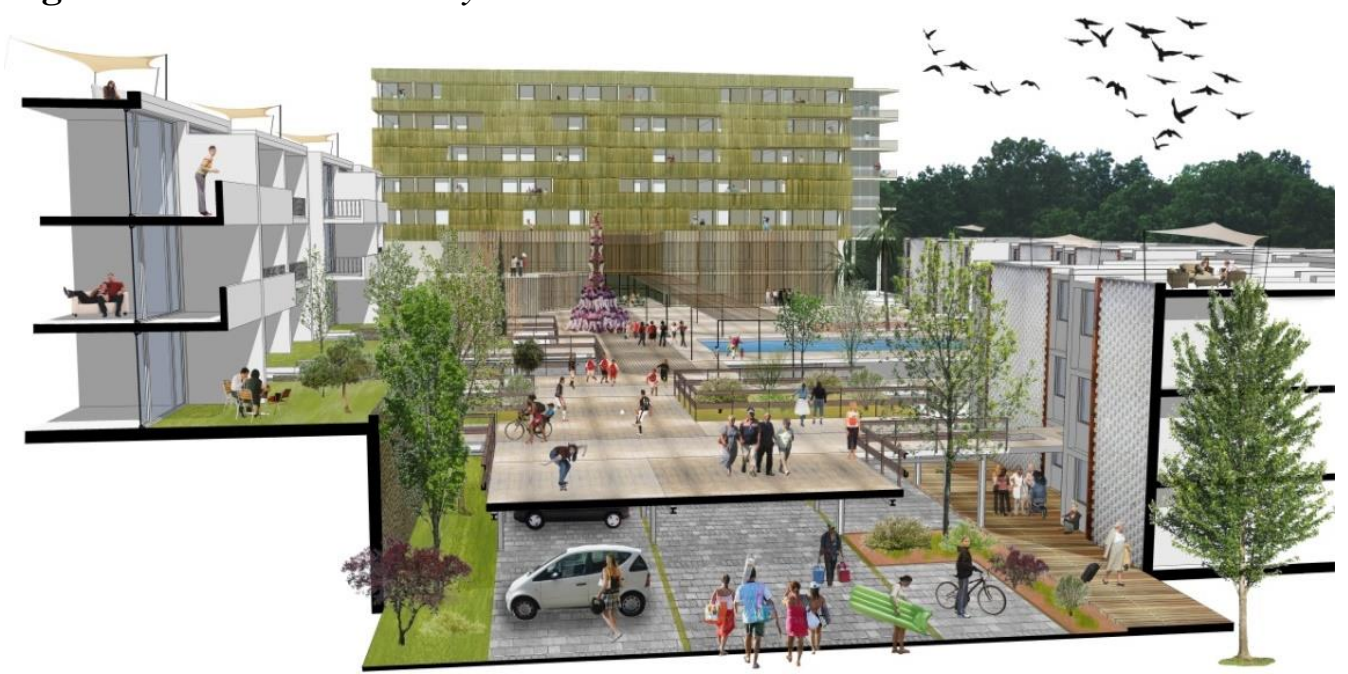

Source: Investigation on Mediterranean Architecture.

To conclude, the process of regeneration has two principal goals: the reconsideration of the current legislation and the implementation of sustainable materials, techniques and processes. The purpose is to reach the maximum optimization of the urban and construction legality and to define regeneration criteria and heritage protection plans that would be useful for town councils, local governments and public or private organisations. With their cooperation we can reach a cross-reading of our territory to solve their historical problems.

\section{Conclusions}

The paper presents the case of regeneration of the factory Anis del Mono in relation to the research project "Strategies for the Sustainable Regeneration of Touristic Settlements on the Mediterranean coast" developed by the research group IAM in the Catalan coast.

This is one of the seven cases developed in this research. As part of the Cultural Heritage type, its research methodology also includes a proposal of rehabilitation for heritage buildings on the waterfront.

In the article is described the research process, which starts from a territorial analysis of the coast, continues with identification of some problematic issues, and finalizes with identification of some representative cases with capacity for acting as a regeneration node related to its environment. After that an architectonical solution for the case study is proposed, in order to extract some general guidelines that could be extended in other similar case studies along the coast.

Before developing a proposal for Anis del Mono, the environment and the causes that have led to the current situation are analyzed. After several meetings with the owners, it was decided to maintain the industrial use, and to supplement it with public and cultural uses. We insist in the rationalization of facilities in relation to different uses and timings, and above all, getting a new 
relationship with the city in a modernized urban landscape, but maintaining the profile of its historical memory. The project is carried out to a detailing scale in relation to the construction and climatic elements designed with sustainability criteria and energy efficiency objectives.

The resolution of this particular project, with the others study cases, provides a number of action criteria to apply in similar cases of building regeneration in the Mediterranean coast landscape. It is a manual of good practices. The objective of this research is providing tools and actions for managing territory, directly related to administrations. For each one of these ways of action is designed an icon, a visible sign that can be used as a seal of quality from those authorities.

So that, the next step for the research project will be to extend the typified solutions to the entire coastline by means of a digital geographic system which will include all the information. It would be possible to display the amount and type of identified problems and also their possible types of intervention. It would be an open tool for the territorial project of this coastal zone with sustainability criteria, useful for both local and territorial administrations.

\section{Acknowledgments}

Our thanks to all the city councils and administrations which have provided us an easy way to work with them. Also thanks to the Economy Department of the Spain Government for subsidizing this research project.

\section{References}

Busquets J (2003) Les formes urbanes del litoral català [Urban forms of Catalan Coast]. Barcelona: Diputació de Barcelona, Xarxa de Municipis.

Busquets J (2004) Comprendre el territori per dissenyar-lo [Understanding territory in order to design it]. Papers 41(9).

IAM Group (2015) Estrategias mediterráneas, La Salle - URL [Mediterranean strategies]. Barcelona: Ulzama. ISBN 978-84-9846-928-8.

Kostof S (2004) The city shapped: Urban patterns and meaning througth history. London: Bulfinch Press.

Mañá F, Cuchi A, Castello D, Diez G, Sagrere A (2003) Parámetros de sostenibilidad [Sustainable parameters]. Barcelona: ITeC.

Marshall S (2005) Streets and patterns. Oxon: Spon Press.

Martí C (1990) Las variaciones de la identidad. Ensayo sobre el tipo en arquitectura [Identity variations. Essay on architectonical typologies]. Milán: Clup.

Monteys X (2014) Rehabitar. La casa, el carrer $i$ la ciutat [Reinhabiting. House, street, city]. Departament Projectes arquitectònics. Barcelona: UPC.

Pardal C, Paricio I (2006) La fachada ventilada y ligera [Ventilated facade and light]. Barcelona: Bisagra.

Ramos Galino FJ, Ramos Sanz A (1995) Intervenir en arquitecturas portantes [Intervening in supporting architectures]. Tectónica 18.

Solà-Morales M (1997) Les formes de creixement urbà [Ways of urban development]. Barcelona: UPC. 